\title{
Urgences
}

\section{Une rocaille en octobre}

\section{Françoise Nadeau}

Numéro 16, mars 1987

D.G. Jones : d'un texte, d'autres

URI : https://id.erudit.org/iderudit/025400ar

DOI : https://doi.org/10.7202/025400ar

Aller au sommaire du numéro

Éditeur(s)

Urgences

ISSN

0226-9554 (imprimé)

1927-3924 (numérique)

Découvrir la revue

Citer ce document

Nadeau, F. (1987). Une rocaille en octobre. Urgences, (16), 74-75.

https://doi.org/10.7202/025400ar d'utilisation que vous pouvez consulter en ligne.

https://apropos.erudit.org/fr/usagers/politique-dutilisation/ 


\section{Françoise Nadeau UNE ROCAILLE EN OCTOBRE}

Sous la pluie, elle est décombres d'ombres, elle est le tombeau des fleurs.

Elle réunit les couleurs des feuilles tombées. Pourtant, ce sont les pierres qui fleurissent

comme une réunion de volumes où ceux qui sont disparus font la conversation.

Ma bouche se remplit de pierres et les ossements de mes collègues

ressemblent à des fleurs.

Est-ce le fouillis, un paradis ou Angkor Vat

ou bien le centre-ville passé

22 heures? Elle n'est ni vivante ni morte

ni humaine. Sous la pluie, je passe à côté, triste. Ce sont des runes en puissance. 
Comment traduire un poème sans risquer de modifier la physionomie du texte original, sans mettre en danger la grâce de ses images, sans changer la cadence de sa musique? Même si ce n'est pas le message de l'auteur qui est habituellement touché lorsqu'un poème passe d'une langue à une autre, ce sont les artifices dont il est paré - la couleur qu'il reflète et le parfum qu'il exhale - qui sont souvent hélas! altérés, transformés, métamorphosés.

C'est, en tout cas, l'impression qu'il me reste après avoir traduit Rock Garden: October de D.G. Jones. Dans ce poème, M. Jones s'applique à mettre en valeur les sons que contient le langage; à l'intérieur de phrases courtes mais intenses, il évoque toute une série d'images. Son poème tient autant de la musique que des sensations. La difficulté en matière de traduction s'en trouve alors accrue.

Dans Rock Garden, les images que M. Jones évoque sont frappantes. En l'espace d'un mot, d'une expression, elles sont là qui défilent dans notre imagination. Elles nous parlent d'amour et de mort, de fleurs et de noirceur. Ainsi, après avoir fait enjamber au poème le mur qui sépare les deux langues, je me retrouve avec un texte français contenant des phrases quelque peu étirées, des images légèrement pâlies et des jeux de mots totalement absents.

Cependant, muni du souci du traducteur pour le détail et de la vive sensibilité d'un poète, $\mathrm{M}$. Jones, lui, ne se laisse pas arrêter par des difficultés de ce genre. Avec une habileté remarquable, il contribue depuis des années à faire connaître les poètes québécois à ses compatriotes anglophones.

Merci, M. Jones. 